\title{
PENGARUH MUSIM TERHADAP PERKEMBANGAN ATELOCAUDA DIGITATA, PENYEBAB PENYAKIT KARAT PADA ACACIA AURICULIFORMIS DI YOGYAKARTA
}

\author{
Siti Muslimah Widyastuti, Harjono, \& Zjakiyah Ari Susanti \\ Fakultas Kehutanan Universitas Gadjah Mada \\ E-mail: smwidyastuti@ugm.ac.id
}

\begin{abstract}
Seasonal effect on the growth of Atelocauda digitata, the cause of rust disease on Acacia auriculiformis in Yogyakarta. The research was aimed to determine the growth of Atelocauda digitata which attacks Acacia auriculiformis in Gunung Kidul, Yogyakarta and determine the process of A. digitata infection on A. auriculiformis. Quantification of the presence of pathogen and the damage as part of tree health monitoring was represented by the percentage of disease incidence and severity, that was used as a benchmark of $A$. digitata dynamics. Pathogenic organisms were confirmed by pathogenicity test. The process of infection was studied microscopically and macroscopically. Percentage of disease incidence and severity of all three observation plots during the rainy and the dry season were dynamic, with the highest damage discovered in Plot 5. A. digitata infecting A. auriculiformis produces three types of spores, namely teliospores, uredospores and aeciospores. The hyphae infected the leaf tissue two days after inoculation through stomata. Intracellular hyphae were found five days after inoculation.
\end{abstract}

Key words: Atelocauda digitata, Acacia auriculiformis, rust disease.

\begin{abstract}
ABSTRAK
Pengaruh musim terhadap perkembangan Atelocauda digitata, penyebab penyakit karat pada Acacia auriculiformis di Yogyakarta. Penelitian ini bertujuan untuk mengetahui perkembangan Atelocauda digitata yang menyerang Acacia auriculiformis di Gunung Kidul, Yogyakarta dan mengetahui proses infeksi jamur Atelocauda digitata pada Acacia auriculiformis. Kuantifikasi keberadaan patogen dan kerusakan yang merupakan bagian dari monitoring kesehatan pohon diwakili dengan persen kejadian dan tingkat keparahan penyakit yang digunakan sebagai tolak ukur dinamika Atelocauda. digitata. Organisme patogen dibuktikan dengan uji patogenisitas. Proses infeksi dipelajari secara mikroskopis dan makroskopis. Persen kejadian dan tingkat keparahan penyakit dari ketiga plot pengamatan selama musim hujan dan kemarau bersifat dinamis dengan kerusakan yang paling tinggi dijumpai pada Petak 5. Atelocauda digitata yang menginfeksi Acacia auriculiformis menghasilkan tiga jenis spora, yaitu teliospora, uredospora dan aesiospora. Melalui lubang alami (stomata), hifa menginfeksi jaringan daun dua hari setelah inokulasi. Hifa intraseluler ditemukan lima hari setelah inokulasi.
\end{abstract}

Kata kunci: Atelocauda digitata, Acacia auriculiformis, penyakit karat.

\section{PENDAHULUAN}

Acacia auriculiformis termasuk famili Leguminosae, berasal dari Australia Utara dan Kepulauan Kei, Maluku, yang mempunyai berbagai manfaat, baik secara ekonomi maupun ekologi. Dari hasil pengamatan pendahuluan di Hutan Pendidikan Wanagama I, diketahui ada serangan Atelocauda digitata pada A. auriculiformis. Di Australia, Asia, dan New Zealand dilaporkan adanya serangan $A$. digitata (Walker, 2001; FAO, 2007), demikian juga di Sumatera Selatan serta Kalimantan (Barry, 2002). Pada awalnya di Hawai A. digitata merupakan patogen sekunder yang menyerang A. auriculiformis. Dalam perkembangannya ternyata penyakit ini telah menjadi salah satu penyakit utama pada Acacia sp. (Nelson, 2009). Informasi mengenai infeksi serta dinamika penyakit ini masih sangat terbatas.

Hutan rakyat $A$. auriculiformis di Wonogiri, Jawa Tengah juga terserang A. digitata (Ismail \& Anggraeni, 2008). Gejala yang ditunjukkan adalah munculnya pembengkakan pada daun, ranting, dan cabang, sedangkan adanya tanda ditunjukkan dengan munculnya teliospora berwarna coklat pada permukaan daun, ranting, dan cabang yang mengalami pembengkakan. Penelitian ini diharapkan mampu menjelaskan tingkat 
perkembangan A. digitata pada A. auriculiformis dan bagaimana proses infeksinya, sehingga persebaran penyakit karat ini dapat dikendalikan.

\section{METODE PENELITIAN}

Tempat dan Waktu. Penelitian dilakukan di dua tempat yaitu di Wanagama I Gunung Kidul, Yogyakarta dan Laboratorium Perlindungan dan Kesehatan Hutan, Fakultas Kehutanan, Universitas Gadjah Mada. Pengamatan di lapangan dilakukan dua kali setahun, yaitu bulan Agustus dan November selama 2 tahun (2008-2009). Pemilihan bulan Agustus dan November untuk mewakili periode musim kemarau dan musim hujan.

Dari beberapa petak yang ada di Wanagama I Gunung Kidul, Yogyakarta digunakan 3 petak untuk pengamatan yaitu pada petak 5, 7 dan 16. Pemilihan ketiga petak pengamatan tersebut karena letak ketiganya menyebar sehingga dapat mewakili kondisi hutan di Wanagama I. Jenis vegetasi pada petak pengamatan dapat dilihat di Tabel 1. Persebaran A. auriculiformis pada ketiga petak tersebut tidak merata, dengan fase pertumbuhannya dari semai sampai tiang (diameter < $20 \mathrm{~cm})$.

Pembuatan Petak Ukur. Petak ukur dibuat dengan menggunakan modifikasi dari Forest Health Monitoring, Field Methods Guide (Alexander \& Barnard, 1995), menggunakan kluster yang terdiri atas 4 subplot dan 4 annular plot.

Intensitas Penyakit dan Luas Serangan. Di setiap petak ukur dilakukan monitoring kesehatan pada masingmasing individu pohon. Gejala penyakit dan keberadaan organisme penyebab penyakit pada tapak diamati berdasarkan pengamatan mikroskopis dan makroskopis. Serangan A. digitata pada A. auriculiformis di ketiga petak, diukur luas serangan dan tingkat keparahannya dengan modifikasi rumus (Chester, 1959)

Luas Serangan $=\frac{\sum \text { tanaman yang terserang }}{\sum \text { total tanaman yang diamati }} \times 100 \%$

Sedangkan tingkat keparahan penyakit suatu tumbuhan pada lokasi tertentu dihitung dengan

$$
\text { Keparahan penyakit }=\frac{\sum(\mathrm{n} \times \mathrm{v})}{\mathrm{N} \times \mathrm{V}} \times 100 \%
$$

$\mathrm{n}=$ jumlah tanaman terserang pada kategori tertentu

$\mathrm{v}=$ kategori serangan tertentu (skor)

$\mathrm{N}=$ jumlah tanaman yang diamati

$\mathrm{V}=$ kategori serangan tertinggi yang digunakan

Tingkat keparahan penyakit setiap sampel diberi nilai (skor) berdasarkan kenampakan keseluruhan setiap individu pohon mengunakan modifikasi pedoman dari Alexander \& Barnard (1995):

$0=$ Sehat (tidak ada gejala dan tanda penyakit).

$1=>0-25 \%$ bagian tanaman menunjukkan gejala dan atau tanda penyakit.

$2=>25-50 \%$ bagian tanaman menunjukkan gejala dan atau tanda penyakit.

$3=>50-75 \%$ bagian tanaman menunjukkan gejala dan atau tanda penyakit.

$4=>75-100 \%$ bagian tanaman menunjukkan gejala dan atau tanda penyakit.

Identifikasi Penyebab Penyakit. Bagian tumbuhan yang menunjukkan gejala dan tanda terserang $A$. digitata diidentifikasi secara mikroskopis. Pengambilan sampel dari pohon berpenyakit di lapangan dilakukan dengan cara memotong daun dan cabang yang sakit. Teliospora diambil dari bagian yang sakit menggunakan jarum ent, diletakkan di atas gelas benda yang telah ditetesi lactophenol trypan blue, ditutup dengan deglass dan

Tabel 1. Jenis vegetasi pada petak pengamatan

\begin{tabular}{clll}
\hline \multirow{2}{*}{ Petak } & \multicolumn{2}{c}{ Jenis vegetasi } \\
\cline { 2 - 4 } & \multicolumn{1}{c}{ Dominan } & \multicolumn{1}{c}{ Minor } \\
\hline 5 & $\bullet$ & Santalumalbum & Schleichera oleosa \\
& $\bullet$ & Acacia auriculiformis. & $\bullet$ Eucalyptus spp. \\
16 & $\bullet$ & Melaleuca leucadendron L. & $\bullet$ Acacia auriculiformis. \\
& & Imperata cylindrica & Swietenia mahagoni \\
& & $\bullet$ Acacia auriculiformis \\
& & $\bullet$ Caesalpinia sappan \\
\hline
\end{tabular}


diamati menggunakan mikroskop cahaya Olympus CX31. Foto mikroskopis diambil dengan menggunakan kamera digital MDCE-5A yang dihubungkan ke komputer dengan menggunakan perangkat lunak ScopePhoto versi 2.0.4.

Uji Patogenisitas. Uji Postulat Koch dilakukan untuk mengetahui apakah jamur yang diperoleh bersifat patogenik atau tidak, meskipun untuk patogen yang tidak dapat ditumbuhkan pada media buatan karena bersifat obligat, prosedur ini tidak dapat dilakukan sepenuhnya. Atelocauda digitata termasuk salah satu jamur yang bersifat parasit obligat, maka uji patogenisitas ini dilakukan dengan cara inokulasi langsung pada daun semai $A$. auriculiformis yang sehat. Teliospora yang terdapat pada permukaan daun dilepas menggunakan kuas kecil, dan ditampung dalam cawan Petri. Teliospora tersebut dilarutkan dalam air steril yang ditambah dengan Tween-20 $(0,02 \%)$ untuk menurunkan tegangan muka sehingga teliospora akan mudah menempel pada permukaan organ tanaman. Daun semai A. auriculiformis diinokulasi dengan suspensi teliospora menggunakan kuas halus. Sebagai kontrol, digunakan air steril yang ditambah dengan Tween-20 (0,02\% v/v). Semai yang telah diinokulasi diinkubasikan dalam kontainer, dijaga kelembaban dan suhunya $\left(25^{\circ} \mathrm{C}\right)$ selama 8 hari (Morris, 1987). Uji patogenisitas ini menggunakan semai dengan umur 8-10 minggu dan tinggi semai antara $510 \mathrm{~cm}$. Gejala yang terbentuk diamati, dilanjutkan dengan pengamatan secara mikroskopis.

Proses Infeksi Atelocauda digitata. Semai A. auricliformis yang sehat diinokulasi buatan dengan meneteskan suspensi teliospora $\left(5 \times 10^{5}\right.$ spora $\left.\mathrm{mL}^{-1}\right) \mathrm{ke}$ permukaan daun. Sampel daun diambil pada hari ke 2, 4, 6 dan 8 setelah inokulasi dengan masing-masing perlakuan tiga kali ulangan. Selanjutnya dilakukan pewarnaan dengan lactophenol trypan blue untuk mengetahui stuktur $A$. digitata dan respon yang ditunjukkan oleh A. auriculiformis. Pengamatan dan pengambilan gambar dilakukan pada hari ke 1, 2, 10 dan 15 setelah inokulasi. Sampel daun dipotong-potong dengan panjang kurang lebih $1 \mathrm{~cm}$, dimasukkan tabung Erlenmeyer $(50 \mathrm{~mL})$ yang telah diisi etanol $20 \mathrm{~mL}$ untuk menghilangkan zat hijau daun. Sampel dalam larutan etanol tersebut dipanaskan hingga mendidih selama 20 menit (Ruzin, 1987).

Setelah zat hijau daun larut, etanol (96\%) diganti dengan larutan chloral hidrat $\left(2,5 \mathrm{~g} \mathrm{ml}^{-1}\right)$ dan dipanaskan selama kurang lebih 20 menit hingga sampel menjadi transparan (Elliott et al., 2008). Sampel ditetesi lactophenol trypan blue, dan diamati menggunakan mikroskop Olympus CX31. Foto mikroskopis dibuat menggunakan kamera digital MDCE-5A yang dihubungkan ke komputer dengan perangkat lunak ScopePhoto versi 2.0.4.

\section{HASIL DAN PEMBAHASAN}

\section{Pengenalan Gejala dan Tanda Penyakit Karat} (Atelocauda digitata). Penyebab penyakit karat pada tanaman A. auriculiformis adalah A. digitata. Patogen karat menyerang pada daun, tangkai daun, pucuk, dan buah A. auriculiformis (Old et al., 2000). Jaringan tanaman yang terinfeksi akan mengalami pembengkakan. Pada penelitian ini, A. digitata menyerang daun, tangkai daun dan pucuk (Gambar 1), sedangkan serangan pada buah tidak ditemukan. Penyakit karat dapat menghambat atau menganggu pertumbuhan tanaman, pada tingkat lanjut dapat menyebabkan kematian organ, dan pada kondisi parah dapat menyebabkan kematian tanaman (Mahfud, 2012).

Berdasarkan hasil pengamatan pertama di tahun pertama pada ketiga petak yang digunakan, A. digitata hanya menyerang $A$. auriculiformis pada tingkat semai sampai tiang di satu petak (petak 5). Hasil ini sesuai dengan peneliti pendahulu bahwa A. auriculiformis merupakan salah satu inang dari A. digitata (Thu et al., 2010).

Dinamika Perkembangan $A$. digitata. Pada tiga petak ukur yang digunakan, dilakukan monitoring perkembangan penyakit. Patogen penyebab penyakit diamati dengan melihat kuantifikasi persen keterjadian dan tingkat keparahan penyakit. Dengan pengumpulan data secara berkala, diharapkan mampu menggambarkan perkembangan serangan patogen pada ketiga tapak yang digunakan.

Untuk mengetahui besar kerusakan hutan yang disebabkan oleh patogen maka pada tahun pertama pengambilan data dilakukan pada semua tanaman yang ada di dalam petak ukur yang terkena penyakit. Sedangkan pada tahun kedua lebih di fokuskan pada A. auriculiformis yang terserang oleh $A$. digitata (Tabel 2). Perubahan fokus pengamatan ini disebabkan karena pada tahun pertama persen keterjadian penyakit pada tanaman A. auriculiformis yang terserang A. digitata sangat tinggi baik pada musim hujan maupun musim kemarau.

Luas serangan dan tingkat keparahan penyakit yang diperoleh memperlihatkan bahwa persebaran A.digitata yang menyerang A. auriculiformis di Gunung Kidul, Yogyakarta sangatlah cepat. Dalam 

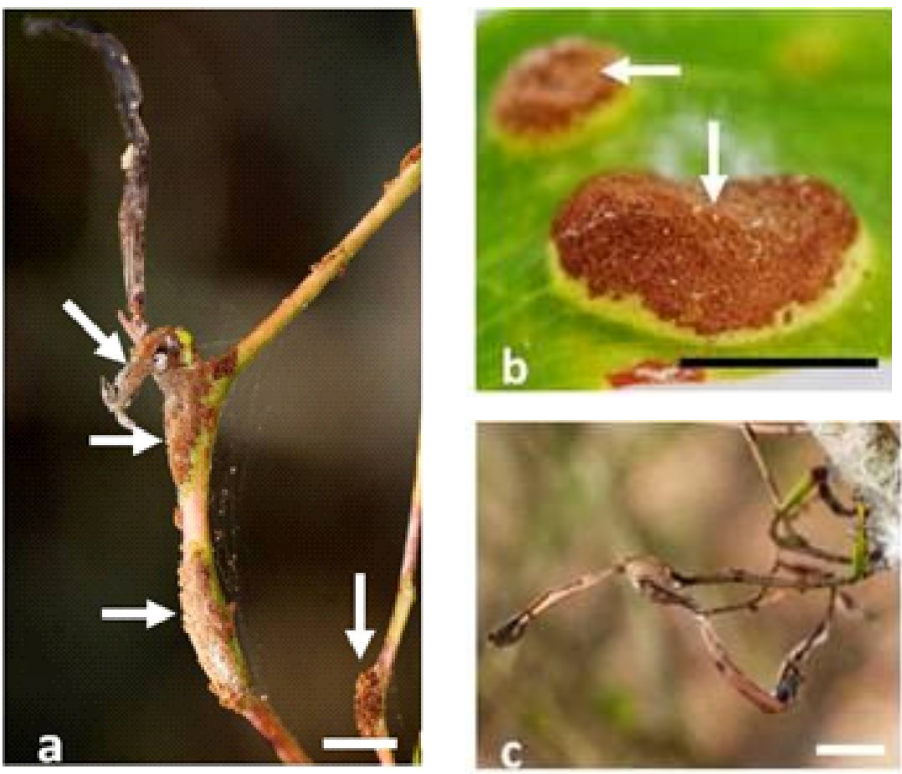

Gambar 1. Penyakit karat pada A. auriculiformis. (a) Pembengkakan ranting dan disertai dengan kematian pucuk, (b) pembengkakan daun (cecidia), dan (c) kematian ranting. Pada permukaan yang terinfeksi (a) dan (b) terdapat jutaan urediniospora, ditandai dengan adanya kumpulan serbuk berwarna cokelat (tanda panah). (Bar: $1 \mathrm{~cm}$ ).

Tabel 2. Persen keterjadian dan tingkat keparahan serangan Atelocauda digitata pada Acacia auriculiformis di petak pengamatan

\begin{tabular}{cccccc}
\hline \multirow{2}{*}{ Petak } & \multirow{2}{*}{ Tahun } & \multicolumn{2}{c}{ \% Keterjadian penyakit ${ }^{\text {a) }}$} & \multicolumn{2}{c}{ Tingkat keparahan penyakit $^{\text {b) }}$} \\
\cline { 3 - 6 } & & Kemarau & Hujan & Kemarau & Hujan \\
\hline 5 & 2008 & 100 & 100 & 57 & 37 \\
& 2009 & 100 & 100 & 79 & 59 \\
7 & 2008 & 0 & 0 & 0 & 0 \\
& 2009 & 35 & 27 & 47 & 30 \\
16 & 2008 & 0 & 0 & 0 & 0 \\
& 2009 & 28 & 23 & 42 & 20 \\
\hline
\end{tabular}

a) Skala $0-100 \%$.

waktu satu tahun jamur penyebab penyakit karat yang pada tahun pertama hanya menyerang 1 petak, pada tahun kedua telah menyerang dua petak yang lain. Penyebaran $A$. digitata sangat luas, karena uredospora patogen mudah terbawa angin. Selain itu penelitian yang dilakukan oleh Triyogo \& Widyastuti (2012) menyimpulkan bahwa serangga juga berperan sebagai vektor dalam penyebaran spora Uromycladium tepperianum penyebab penyakit karat tumor pada Falcataria mollucana.

Pada petak 5 , baik pada pengamatan tahun pertama maupun tahun kedua diketahui bahwa keterjadian penyakit sudah 100\% (Tabel 2). Tabel 2 juga menjelaskan bahwa pada tahun kedua, keterjadian penyakit pada petak 7 dan petak 16 yang tadinya $0 \%$ mulai menunjukkan adanya penyebaran patogen, walaupun nilai persen keterjadian penyakitnya masih lebih kecil dibanding petak 5 .

Tingkat keparahan penyakit dan luas serangan di ketiga petak pada musim hujan menurun (Tabel 2). Hal ini terjadi karena trubusan baru belum terserang $A$. digitata sehingga persentase yang dihasilkan dari persentase keterjadian penyakit akan lebih kecil dibanding pada musim kemarau. Pada musim kemarau seluruh daun A. auriculiformis terserang A. digitata, 
selain itu trubusan tidak terjadi sehingga persentase keterjadian penyakit menjadi tinggi.

Dari hasil pengamatan di petak uji diperkirakan pada tahun-tahun selanjutnya keparahan penyakit dan luas serangan akan semakin meningkat. Apabila tidak dilakukan pengendalian terhadap serangan patogen karat ini, persebaran A. digitata akan meluas ke petak-petak yang lain.

Perkembangan Spora A. digitata. Siklus hidup A. digitata sangat unik, termasuk dalam kategori macrocyclic karena mempunyai lima stadia spora dalam satu siklus hidup dengan dua jenis inang, yaitu uredospora, teliospora, sporidium, pikniospora dan aeciospora (Agrios, 2005). Infeksi jamur ini bersifat sistemik (Chen et al., 1996), yaitu patogen dari titik awal infeksi, menyebar dan menyerang sebagian besar atau seluruh sel jaringan yang rentan. Penyakit karat termasuk biotrof, karena patogen hanya dapat tumbuh dan berkembang biak secara alami pada inang yang hidup, atau sering disebut parasit obligat (Ismail \& Anggraeni, 2008).

Menurut Worall (2007), dalam satu siklus hidup A. digitata menghasilkan lima jenis spora yang berbeda dari fase piknium, aesium, uredium, telium dan promiselium. Proses perkecambahan $A$. digitata diawali dari aesium. Aesium menghasilkan aesiospora (2n) dan pada daun tanaman membentuk uredium yang menghasilkan urediospora. Pada tahap berikutnya urediospora akan membentuk telium yang menghasilkan teliospora. Selanjutnya teliospora ini akan membentuk spermagonium, dan pada proses itu akan dihasilkan spermatia (n) yang akan membentuk aesium lagi (Gambar 2). Pada umumnya urediospora yang berterbangan di udara akan dapat menginfeksi jaringan tanaman yang baru.

Kecepatan angin rata-rata di Gunung Kidul, Yogyakarta pada tahun 2009 adalah sebesar 11,75 knot (Anonim, 2010) sehingga mampu menyebarkan uredospora ke beberapa petak lainnya. Dalam proses perkecambahan spora, suatu jamur akan bergantung pada kepatahan dormansi, faktor lingkungan dan faktor fisiologis yang terlibat dalam perkecambahan.

Pada pengamatan mikroskopis di penelitian ini, ditemukan tiga fase pembentukan spora yaitu teliospora, uredospora dan aesiospora (Gambar 3) sedangkan bentuk sporidia dan spermatia tidak dijumpai. Berbeda dengan $A$. digitata yang menyerang tanaman $A$. mangium, fase yang dijumpai adalah fase piknium, uredium, dan telium sedangkan dua fase yang lain, yaitu aesium dan promiselium, tidak ditemukan (Santoso et al., 2003).
A. digitata yang menyerang A.auriculiformis mempunyai sifat heterocious karena sebagian dari fase hidupnya terdapat pada inang yang berbeda. Dengan ditemukannya fase telium pada pengamatan mikroskopis ini menunjukkan bahwa A. auriculiformis merupakan inang primer, karena pada fase ini akan dibentuk spermatogonium yang menghasilkan spermatia. Pada tahap selanjutnya, akan terbentuk aesium lagi.

Infeksi $A$. digitata. Gejala awal A. auricuriformis yang terinfeksi oleh $A$. digitata secara makroskopis adalah adanya bercak yang berwarna hijau kekuningan sampai kuning. Bercak ini kemudian menebal, membentuk gall serta terlihat adanya perubahan bentuk dan ukuran sel-sel daun menjadi tidak beraturan. Sel daun yang sakit ukurannya relatif lebih besar (membengkak) dibandingkan dengan sel-sel yang ada pada daun sehat (Gambar 1b).

Secara mikroskopis jaringan yang terinfeksi $A$. digitata ditandai dengan adanya sekumpulan miselium yang terbentuk seperti bukit yang lebih dikenal dengan piknium atau spermogonium. Dengan terbentuknya sekumpulan miselium di dalam jaringan daun maka sel yang berada di sekitar piknium mengalami perubahan bentuk dan ukuran, bahkan pada bagian-bagian tertentu timbul kerusakan. Fase aesium, merupakan fase permulaan timbulnya infeksi, yang dilanjutkan dengan fase uredium dan telium. Kedua fase ini sering dijumpai dalam kelompok wadah-wadah yang berbentuk seperti cawan yang tersambung keluar menembus lapisan epidermis dan kutikula. Teliospora berukuran lebih besar dari pada uredospora, kadang-kadang dijumpai tonjolan atau papila atau germ tube sebagai awal perkecambahan spora. Promiselium atau basidium merupakan fase terakhir pada infeksi $A$. digitata.

A. digitata mempunyai cara khusus untuk masuk ke dalam jaringan inang yaitu dengan metode penetrasi melalui stomata. Gambar 4 memperlihatkan spora A. digitata pada inokulasi buatan berkecambah. Tabung kecambah tumbuh pada stomata, kemudian membentuk apresorium, dan pada hari kedua ditemukan satu bentuk hifa yang tumbuh masuk ke dalam stomata (Gambar 4a). Lima hari setelah inokulasi ditemukan hifa intraseluler pada jaringan yang terinfeksi (Gambar 4b). Teliospora ditemukan pada permukaan daun yang terinfeksi 15 hari setelah inokulasi (Gambar 4c). Diduga A. digitata dapat menyelesaikan sebagian atau bahkan satu siklus hidupnya dalam satu tahun. Patogen yang memiliki kemampuan ini disebut patogen monosiklik. Pada umumnya jamur karat menghasilkan spora pada akhir musim kering. Spora tersebut berfungsi sebagai inokulum primer pada musim hujan, dan sebagai satu- 


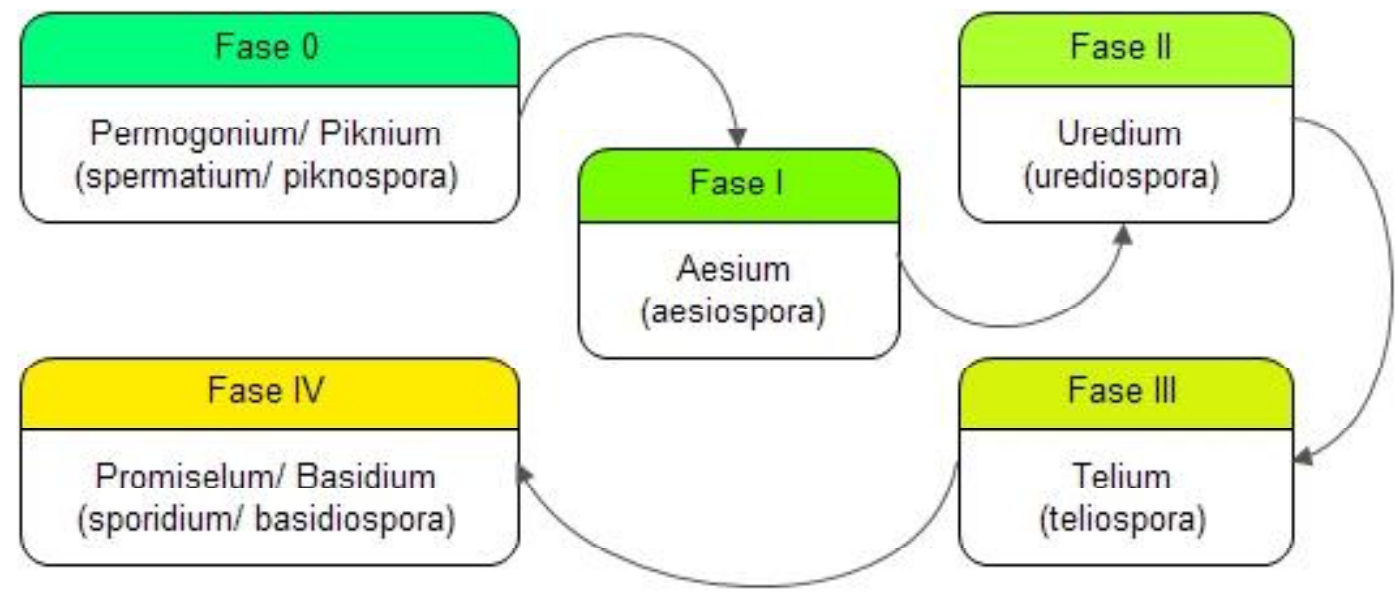

Gambar 2. Lima fase spora Atelocauda digitata (Santoso et al., 2003; Worall, 2007).
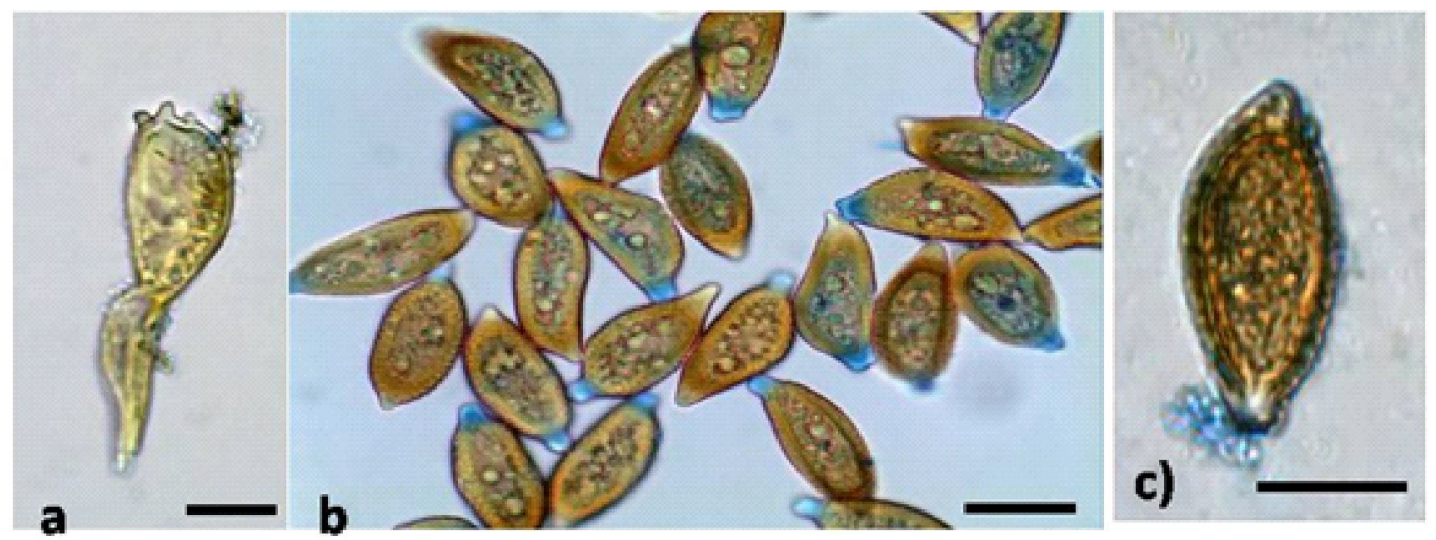

Gambar 3. Spora Atelocauda digitata. (a) teliospora, (b) urediospora, dan (c) aesiospora (Bar: $20 \mu \mathrm{m}$ ).
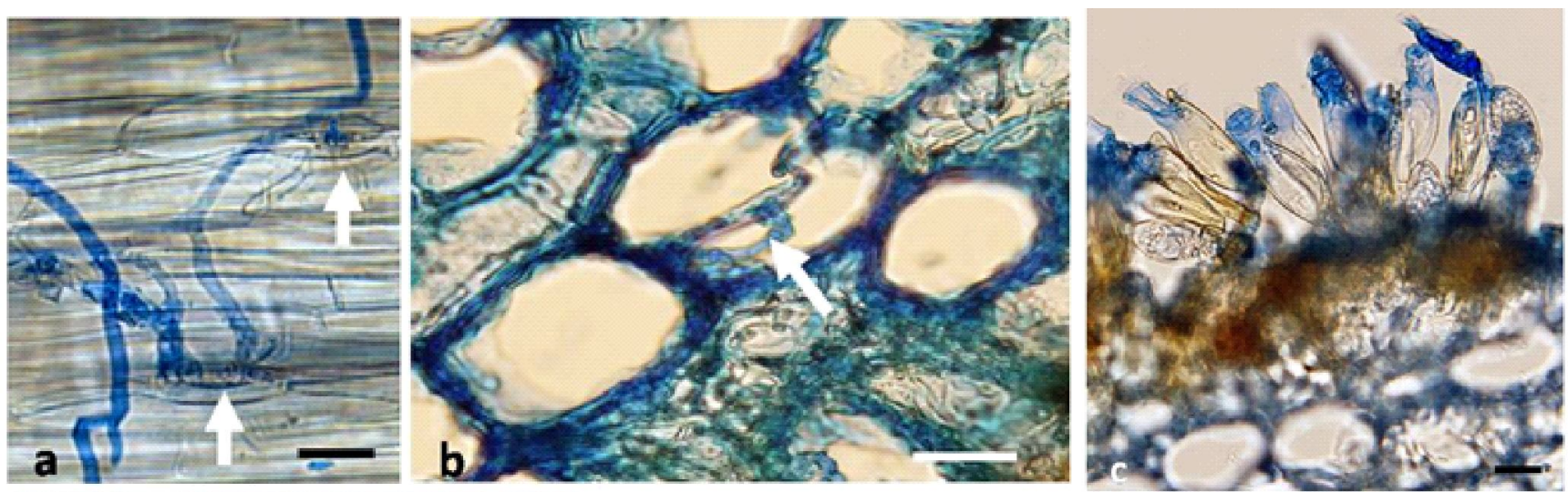

Gambar 4. Infeksi Atelocauda digitata pada daun Acacia auriculiformis. (a) Penetrasi hifa via lubang stomata (tanda panah) dua hari setelah inokulasi, (b) hifa intraseluler (tanda panah) lima hari setelah inokulasi, dan (c) teliospora pada permukaan daun, 15 hari setelah inokulasi. Bar $=20 \mu \mathrm{m}$. 
satunya sumber inokulum pada awal tahun berikutnya. Atelocauda digitata juga dapat menginfeksi secara sistemik, sehingga akan menyulitkan proses pengendalian yang tepat.

Inokulasi patogen pada tanaman tidak selalu diikuti dengan proses infeksi. Hal ini mirip dengan hasil penelitian Widyastuti et al. (2013) yang melakukan inokulasi buatan menggunakan inokulum teliospora $U$. tepperianum dari tanaman sengon pada filodia A. mangium yang menunjukkan bahwa infeksi tidak terjadi. Hasil penelitian ini berbeda dengan hasil infeksi yang terjadi di alam, teliospora membentuk basidiospora terlebih dahulu baru kemudian membentuk pasak penetrasi dan melakukan penetrasi pada jaringan tanaman. Selama proses infeksi pada sengon di alam, teliospora $U$. tepperianum yang berada pada permukaan jaringan berkecambah untuk membentuk basidiospora (Rahayu et al., 2010). Keberhasilan terjadinya interaksi antara patogen dengan inang ditentukan oleh berbagai faktor. Inokulum yang mampu berada di dekat atau tepat pada tapak infeksi merupakan faktor yang sangat penting pada proses infeksi. Kondisi lingkungan, sifat permukaan tumbuhan, keberadaan senyawa penghambat dan adanya agen antagonis juga ikut berperan dalam keberhasilan inokulasi.

\section{SIMPULAN}

Luas serangan dan tingkat keparahan penyakit karat pada A. auriculiformis bersifat dinamis. Pada musim hujan, intensitas penyakit menurun karena tumbuhnya daun dan ranting baru. A. auriculiformis di Wanagama I Gunung Kidul, Yogyakarta yang terserang A. digitata memproduksi tiga jenis spora yaitu aesiospora, uredospora, dan teliospora. Pikniospora dan basidiospora belum ditemukan. A. digitata menginfeksi daun A. auriculiformis melalui lubang alami yaitu stomata.

\section{SANWACANA}

Penelitian ini didanai dengan Dana DPP Fakultas Kehutanan UGM Tahun anggaran 2009 dengan penulis kedua sebagai peneliti utamanya. Terima kasih juga diucapkan kepada I. Riastiwi atas bantuan teknisnya dalam mempersiapkan manuskrip ini.

\section{DAFTAR PUSTAKA}

Agrios GN. 2005. Plant Pathology. Fifth edition. UK: Elsevier Academic Press. London
Alexander SA \& Barnard JE. 1995. Forest Health Monitoring: Field Methods Guide. Enviromental Monitoring System Laboratory. Las Vegas.

Anonim. 2010. Data Base Daerah Kabupaten Gunung Kidul Tahun 2009.

Barry K. 2002. Heartrots in Plantation Hardwoods in Indonesia and Australia. ACIAR Technical Reports No. 51e.

Chester KS. 1959. How Sich is The Plant? dalam Horsfall J.G. dan Diamond,A. F., (eds). Plant Pathology Press. New York, London

Chen WD, Gardner ED, \& Webb DT. 1996. Biology and life cycle of Atelocauda koae, an unusual demicyclic rust. Mycosience 37: 91-98.

Elliott CE, Harjono, \& Howlett BJ. 2008. Mutation of a gene in fungus Leptosphaeria maculans allows increased frequency of penetration of stomata apertures of Arobidopsis thaliana. Molecular Plant 3: 471-481.

FAO. 2007. Over View of Forest Pest in Indonesia. Forest Health and Biosecurity Working Papers. Rome, Italy.

Ismail B \& Anggraeni I. 2008. Identifikasi penyakit jati (Tectona grandis) dan akasia (Acacia auriculiformis) di hutan rakyat Kabupaten Wonogiri, Jawa Tengah. J. Pemuliaan Tanaman Hutan. 2(1): 1-12.

Mahfud MC. 2012. Teknologi dan strategi pengendalian penyakit karat daun untuk meningkatkan produksi kopi nasional. J. Pengembangan Inovasi Pertanian 5(1): 44-57.

Morris MJ. 1987. Biology of the acacia gall rust, Ucromyclodium tepperianum. Plant Pathol. 36: 100-106.

Nelson S. 2009. Rusts of Acacia koa: Atelocauda digitata (Gall Rust). College of Tropical Agriculture and Human Resources University of Hawaii at Manoa. Hawaii.

Old KM, See LS, Sharma JK, \& Yuan ZQ . 2000. A Manual of Diseases of Tropical Acacia in Australia, South-East and India. Center for Internasional Forestry Research (CIFOR), Jakarta. 
Rahayu S, Lee SS, \& Shukor NAA. 2010. Uromycladium tepperianum, the gall rust fungus from Falcataria moluccana in Malaysia and Indonesia. Mycoscience 51(2): 149-153.

Ruzin SE. 1987. Plant Microtechnique and Microscopy. Oxford University Press, USA.

Santoso E, Nurfarida YI, \& Sitepu IR. 2003. Penyakit karat pada Acacia mangium Willd. Buletin Penelitian Hutan 637: 39-48.

Thu PQ, Griffiths MW, Pegg GS, McDonald JM, Wylie FR, King J, \& Lawson SA. 2010. Healthy Plantations: a Field Guide to Pest and Pathogens of Acacia, Eucalyptus, and Pinus in Vietnam. Departement of Employed. Economic Development and Innovation, Queesland, Australia.

Triyogo A \& Widyastuti SM. 2012. Peran serangga sebagai vektor penyakit karat puru pada sengon (Albizia falcataria L. Fosberg). J. Agron. Indon. 40(1): 77-82.
Walker J. 2001. A revision of the genus of Atelocauda (uredinales) and description of Racospermyces gen. nov. for some rusts of Acacia. Australasian Mycologist 20(1): 3-28.

Widyastuti SM, Harjono, \& Surya ZA. 2013. Infeksi Awal Jamur Uromycladium tepperianum pada daun Falcataria moluccana dan Acacia mangium di Laboratorium. J. Man. Hut. Trop. 19(3): 187-193.

Worall J. 2007. Forest and Shade Tree Pathology. Rust. http://www.forestpathology.org./ rust.html. (10 Februari 2013). 